\title{
Organic fertilization and crop load in yield and quality of organic nectarines in Italy
}

\author{
Caroline Farias Barreto ${ }^{1}$, Luis Eduardo Correa Antunes ${ }^{2}$, Moreno Toselli \\ Elena Baldi ${ }^{4}$, Giovambattista Sorrenti ${ }^{5}$, Maurizio Quartieri ${ }^{6}$
}

\begin{abstract}
Organic fertilization in orchards aims at increasing soil fertility, at impacting plant productivity and environmental sustainability. This study aimed at verifying the effects of organic fertilization and fruit load on two nectarine cultivars with high and low fruit loads. The experiment was carried out in an orchard under organic management in Fratta Terme, Po valley, in northeastern Italy. Nectarine cultivars Big Top and Carene, implemented in 2017 and grafted onto GF677, were used. Three levels of compost (0,20 and $40 \mathrm{t} \mathrm{dw} \mathrm{ha-1)} \mathrm{were} \mathrm{combined} \mathrm{with} \mathrm{two} \mathrm{fruit} \mathrm{loads} \mathrm{(low} \mathrm{and} \mathrm{high)}$ to set up a factorial experimental design with two factors and four randomized replicates. Compost was incorporated at $20 \mathrm{~cm}$ depth. The following parameters were evaluated: nitrate- and ammonium$\mathrm{N}$ concentrations in soil at $20-40 \mathrm{~cm}$ depth, macro and micronutrients in leaves, tree yield, number of fruits, fruit mass and diameter, soluble solids and pulp firmness. The supply of compost enhanced nitrate-N release in soil. In both cultivars, macro- and micronutrient concentrations in leaves were not affected by organic fertilization or fruit load, except for iron, which increased as a consequence of the compost supply. Low crop load induced higher fruit size in both varieties, a fact that was observed after pit hardening. However, the organic fertilization rate did not influence tree yield, fruit mass and soluble solids.
\end{abstract}

Index terms: nitrate-N, ammonium-N, compost, production indexes, leaf nutrients.

\section{Fertilização orgânica e carga de frutas na produtividade e qualidade de nectarinas orgânica na Itália}

\begin{abstract}
Corresponding author: carol_fariasb@hotmail. com

Received: March 05, 2021 Accepted: July 22, 2021

Copyright: All the contents of this journal, except where otherwise noted, is licensed under a Creative Commons Attribution License.
\end{abstract}

\section{$(\mathrm{cc}) \mathbf{E Y}$}

Resumo- A fertilização orgânica em pomares visa a aumentar a fertilidade do solo e a impactar a produtividade das plantas e a sustentabilidade ambiental. $\mathrm{O}$ objetivo deste trabalho foi verificar os efeitos da adubação orgânica e da carga de frutos em duas cultivares de nectarina conduzidas com alta e baixa carga de frutos. O experimento foi realizado em um pomar sob manejo orgânico, em Fratta Terme, no nordeste do vale do Pó, na Itália. Foram utilizadas as cultivares de nectarina Big Top e Carene, implantadas em 2017 e enxertadas em GF677. Três níveis de composto $(0 ; 20$ e 40 t ms ha-1) foram combinados com duas cargas de frutas (baixa e alta) para estabelecer um delineamento experimental fatorial com dois fatores e quatro repetições casualizadas. Esse composto foi incorporado a $20 \mathrm{~cm}$ de profundidade. Foram avaliados os seguintes parâmetros: concentração de nitrato e amônio-N no solo a 20 - $40 \mathrm{~cm}$ de profundidade, macro e de micronutrientes nas folhas, produtividade, número de frutos, massa e diâmetro do fruto, sólidos solúveis e firmeza da polpa. $\mathrm{O}$ fornecimento de composto aumentou a liberação de nitrato-N no solo. Em ambas as cultivares, as concentrações de macro e de micronutrientes nas folhas não foram afetadas pela fertilização orgânica ou pela carga de frutos, exceto para o ferro, que aumentou como consequência do fornecimento de composto. A baixa carga de colheita induziu maior tamanho de fruto em ambas as variedades, que foi observado após o endurecimento do caroço. Ao mesmo tempo, a taxa de fertilização orgânica não influenciou a produtividade das árvores, a massa do fruto e os sólidos solúveis.

Termos para Indexação: nitrato-N, amônio-N, composto, índices de produção, nutrientes foliares.

\footnotetext{
${ }^{1} \mathrm{PhD}$ in Agronomy, Universidade Federal de Pelotas, Pelotas-RS, Brazil.Email: carol_fariasb@hotmail.com (ORCID 0000-0002- 5568-5305) ${ }^{2} \mathrm{PhD}$, Researcher at Embrapa Fruticultura Clima Temperado, Pelotas-RS, Brazil. Email: luis.antunes@embrapa.br (ORCID 0000-0002-0341-1476)

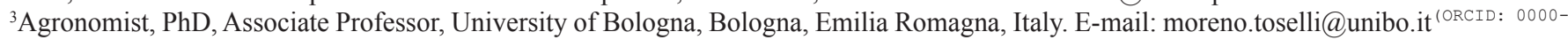
0001-5632-6331)

${ }^{4}$ Agronomist, PhD, University of Bologna, Bologna, Emilia Romagna, Italy. E-mail: elena.baldi7@unibo.it(ORCID 0000-0002-1468-5739)

${ }^{5}$ Agronomist, PhD, University of Bologna, Bologna, Emilia Romagna, Italy. E-mail: g.sorrenti@unibo.it (ORCID 0000-0002-6623-2483)

${ }^{6}$ Agronomist, MSc, Laureate Technician, University of Bologna, Bologna, Emilia Romagna, Italy. E-mail: maurizio.quartieri@unibo. it (ORCID: 0000-0003-2476-0541)
} 


\section{Introduction}

Adequate management of soil organic matter (SOM) and nutrients availability are factors that ensure nutritional balance in orchards and, consequently, fruit productivity and quality. In traditional fruit tree cultivation, excessive use of mineral-based fertilizers in the long run may affect the ecosystem due to risks of leaching and/or emission of nitrogen $(\mathrm{N})$ into the atmosphere. Therefore, sustainable alternatives, such as the use of organic fertilizers, should be employed to carry out nutrient management in plants (BALDI; TOSELLI, 2014; BALDI et al., 2016; TOSELLI et al., 2019a).

Organic fertilizers are cheap, release nutrients slowly, improve soil chemical, biological and physical fertility (WOOLF et al., 2010; POWLSON et al., 2011; SCIUBBA et al., 2015; BALDI et al., 2016; ROUSSOS et al., 2017), with benefits on water and nutrient retention. Compost can be obtained from several organic sources and has been extensively applied to fruit orchards thanks to its positive effects on soil properties (DIACONO; MONTEMURRO, 2010; BALDI et al., 2016; SORRENTI; TOSELLI, 2016) and fruit production in comparison to mineral fertilizers (ROUSSOS et al., 2017). Although there are studies in the literature on the effect of compost of nectarine orchard (BALDI et al., 2016), the increasing interest on sustainable management techniques and on organic production, more research should be carried out with different cultivars, types of compost and doses.

Compost results from aerobic stabilization of residues of several organic substrates (SORRENTI; TOSELLI, 2016) and its use in agriculture enables to recycle urban organic residues and agri-food wastes providing environmental advantages (BALDI et al., 2016). When applied to the soil, compost may increase the concentration of total organic carbon (C) and, consequently, SOM over the years (CABALLERO et al., 2009; BALDI et al., 2016). In addition, compost represents a source of nutrients, such as N, phosphorus $(\mathrm{P})$, potassium $(\mathrm{K})$, calcium $(\mathrm{Ca})$ and magnesium $(\mathrm{Mg})$ (SMITH; COLLINS, 2007; CABALLERO et al., 2009; GOSS et al., 2013).

While a positive effect of organic amendments on fruit yield was observed in several species (MAHADEEN, 2009; BOZKURT et al., 2010; ASLANTAS et al., 2013), contrasting results on the effect of organic fertilization on fruit quality and nutraceutical value are reported in literature (PRANGE, 2015). Several evidences report a positive effect of organic fertilization on fruit color, weight, size, total sugars and anthocyanin contents (MARZOUK; KASSEM, 2011; TAN et al., 2018; AMARANTE et al., 2008). However, opposite results were reported in apples (AMIRI; FALLAHI, 2009) and kiwi fruit (AMODIO, et al. 2007).
Besides fertilization, orchard productivity and fruit quality may be affected by fruit load, since plants with high fruit load suffer competition for nutrients and $\mathrm{C}$ between productive (FARIAS et al., 2019) and vegetative growth (BUSSI et al., 2009). In case of high crop load plants produce a large number of fruits with small size and a consequent low commercial value. In order to avoid excess of fruit in plants, crop load must be regulated according to tree vigor (OLIVEIRA et al., 2017). A possible alternative, could be the increase of soil nutrient availability that may compensate the higher number of fruit and make production corresponding to the required standard of fruit size. Therefore, this study aimed at evaluating the effect of rate of compost application on fruit size, yield and quality in high and low fruit crop load.

\section{Material and methods}

The experiment was carried out in 2019, in an orchard located in Fratta Terme (FC, Italy), in the northeastern part of the Po valley ( $44^{\circ} 8$ ' $\left.34^{\prime \prime} \mathrm{N}, 12^{\circ} 6^{\prime} 3^{\prime \prime} \mathrm{E}\right)$, under organic management in conversion to biodynamic. The study was conducted on two varieties of nectarine $(P$. persica var. nucipersica L.) Big Top and Carene, grafted on GF677 (P. persica x P. dulcis), planted in 2017, trained as in a spindle system, with a spacing of $4 \mathrm{~m}$ between rows and $3 \mathrm{~m}$ between trees on the row, which led to 833 plants per hectare. The characteristics soils of the orchard are summarized in Table 1.

Three levels of compost $\left(0,20\right.$ and $\left.40 \mathrm{tdw} \mathrm{ha}^{-1}\right)$ were combined with two fruit loads (low and high) to set up a factorial experimental design with two factors and four randomized replicates, of 3 trees each. All measurements were made on the central one. Compost, made of municipal organic wastes mixed with garden management residues, was applied on a $2 \mathrm{~m}$ wide tree row on October 2018 and, tilled into the soil to a depth of $20 \mathrm{~cm}$.

When nectarine trees were in full bloom, thinning of flowers was carried out in all plants by a mechanical thinner (Darwin PT-250; Fruit-Tec, Deggenhauserertal, Germany). Forty days after full bloom, two fruit loads were established by no fruitlets thinning in the high fruit load, and manually removal of $33 \%$ of the fruit lets in the low fruit load.

From January to July, monthly soil samples were collected to evaluate nitrate $\left(\mathrm{NO}_{3}^{-}-\mathrm{N}\right)$ and ammonium $\left(\mathrm{NH}_{4}^{+}-\mathrm{N}\right)$ at $20-40 \mathrm{~cm}$ of depth. Nitrate-N and $\mathrm{NH}_{4}{ }^{+}-\mathrm{N}$ were determined by adding $100 \mathrm{~mL}$ of $\mathrm{KCl}(2 \mathrm{M})$ to $10 \mathrm{~g}$ of soil, samples were shaken at $100 \mathrm{rpm}$ for $1 \mathrm{~h}$ and after soil sedimentation, limpid solution was collected and stored at $-20^{\circ} \mathrm{C}$ until analysis with a colorimetric method was made with an auto analyzer (Auto Analyzer AA-3 Bran + Luebbe Nordestadt, Germany). 
Table 1. Soil physical and chemical characteristics at the beginning of the trial

\begin{tabular}{lcc}
\hline Soil characteristics & Cv. Carene & Cv. Big Top \\
\hline Sand (\%) & 41 & 40 \\
Silt (\%) & 45 & 44 \\
Clay (\%) & 14 & 16 \\
$\mathrm{Ph}$ & 7.99 & 8.03 \\
Organic Carbon (\%) & 1.19 & 1.22 \\
Total N (\%) & 1.37 & 1.36 \\
$\mathrm{P}_{2} \mathrm{O}_{5}$ Olsen (mg kg $\left.{ }^{-1} \mathrm{DW}\right)$ & 165 & 66 \\
$\mathrm{~K}_{2} \mathrm{O}$ extractable (mg kg-1 DW) & 377 & 298 \\
$\mathrm{Ca}$ carbonate (mg kg-1 DW) & 2304 & 2613 \\
Mg (mg kg-1 DW) & 166 & 148 \\
$\mathrm{C} / \mathrm{N}$ & 8,72 & 8,96 \\
Cation exchange capacity (meq $\left.100 \mathrm{~g}^{-1} \mathrm{DW}\right)$ & 14.0 & 15.2 \\
\hline
\end{tabular}

$\mathrm{DW}=$ dry mass

In July in fruit harvest, a 20 leaf-sample was collected from each plot, washed, dried at $65^{\circ} \mathrm{C}$ and ground $(<2 \mathrm{~mm})$. Afterwards, $300 \mathrm{mg}$ of sample was mineralized by microwave (Ethos TC Milestone, Bergamo, Italy), with the use of $8 \mathrm{~mL} \mathrm{HNO}_{3}(65 \%)$ and $2 \mathrm{~mL} \mathrm{H}_{2} \mathrm{O}_{2}$ (30\%). Concentration of $\mathrm{P}, \mathrm{K}, \mathrm{Ca}, \mathrm{Mg}$, sulphur (S), iron $(\mathrm{Fe})$, manganese $(\mathrm{Mn})$, copper $(\mathrm{Cu})$ and zinc $(\mathrm{Zn})$ was determined by a plasma spectrophotometer (Ametek Spectro, Acros, Kleve, Germany). N concentration was measured by the Kjeldahl method, which involved hot mineralization $\left(420^{\circ} \mathrm{C}\right)$ of $300 \mathrm{mg}$ of sample with sulfuric acid $\left(\mathrm{H}_{2} \mathrm{SO}_{4}, 97 \%\right)$, in presence of a catalyst based on potassium and copper sulphate, and subsequent distillation with $\mathrm{NaOH}(32 \%)$ and titration with $\mathrm{H}_{2} \mathrm{SO}_{4}(0.1 \mathrm{~N})$.

Fruit growth was weekly evaluated on 20 fruits per plant by a digital caliper. At harvest, tree yield and the number of fruits per plant were measured, and mean fruit weight was determined. In the second and main harvest (on June $28^{\text {th }}$ and July $4^{\text {th }}$ for Carene and Big Top, respectively), a 20-fruit sample per plot was used to measure pulp firmness by an FTA 53220 digital penetrometer (Güss, Strand, South Africa), with a tip of 8-mm in diameter. Soluble solids concentration (SSC) of fruit juice was determined by a digital refractometer (PR-1, Atago, Tokyo, Japan). All data were submitted to the analysis of variance by the F-test. When the effect was significant, the Tukey's test was carried out at $5 \%$ probability. Statistical analyses were conducted by SISVAR version 5.6 (FERREIRA, 2014).

\section{Results and discussion}

To cultivar Carene, the application of compost (no matter the rate) increased $\mathrm{NO}_{3}^{-} \mathrm{N}$ concentration in soil, in comparison with unfertilized control in the first five months after application (Table 2). In June soil $\mathrm{NO}_{3}{ }^{-} \mathrm{N}$ concentration was higher in control than in amended plots; in July the supply of compost at $40 \mathrm{t} \mathrm{ha}^{-1}$ induced an increase of soil nitrate in comparison to control, while compost $20 \mathrm{t} \mathrm{ha}^{-1}$ induced intermediate values (Table 2).

In January, in the soil of Big Top, compost 40 $t \mathrm{tha}^{-1}$ enhanced nitrate concentration in comparison to control, while compost 20 induced intermediate values (Table 2). The supply of compost at $40 \mathrm{tha}^{-1}$ induced the highest $\mathrm{NO}_{3}^{-}-\mathrm{N}$ concentrations between February and May. No significative differences between treatments were observed in June and July (Table 2).

Ammonium-N concentration in soil was lower than the nitrate-N (Tables 2 and 3), because in well-drained soil it is quickly transformed into nitrate by microbial activity. Thus, difference in ammonium concentration was only found in January, when the highest amount was found as a consequence of compost addition at the rate of $40 \mathrm{tha}^{-1}$ only in the cultivar Carene (Table 3 ).

In our experimental condition, mild temperatures at the end of winter and regular rainfalls stimulated microorganisms toward mineralization of organic matter. In addition, the compost used in the experiment had a $\mathrm{C}: \mathrm{N}$ ratio near 10 that allowed the microorganisms involved in the decomposition process to release $\mathrm{N}$ in soil. These are the main reasons why values of nitrate in soil fertilized with both rates of compost from January to April were higher than the optimal demand of peach trees, that is considered between 15-20 $\mathrm{mg} \mathrm{kg}^{-1} \mathrm{NO}_{3}^{-}-\mathrm{N}$ (TAGLIAVINI, et al., 1996). Therefore, in our experimental condition, the application rates were higher than the tree requests and the kinetic of $\mathrm{N}$ release did not meet the tree requirement. Consequently, compost should be applied in different growth stages of plants in order to keep $\mathrm{NO}_{3}^{-}-\mathrm{N}$ available throughout the period according to plants needs and avoid its excess in the soil. 
Nitrate decrease was observed in June probably as a consequence of heavy rainfall that took place in May probably causing surface runoff and nitrate leaching (Figure 1) as also evidenced by Lorensini and coauthors (2012). Besides leaching, the decrease of nitrate concentration could be due to tree root absorption or migration to deeper soil layers.
Organic fertilization and fruit load did not show interaction and any effect on macronutrients leaves concentration of both cultivars (Tables 4 and 5). In Carene the concentration of micronutrients was not influenced by compost supply or crop load; only exception was Fe, which increased as a consequence of compost addition, no matter the rate (Table 4). Iron leaves concentration increased as a consequence of compost addition at the rate of $40 \mathrm{t} \mathrm{ha}^{-1}$ if compared to control, while compost at $20 \mathrm{t}$ $\mathrm{ha}^{-1}$ evidenced intermediate values not different from other treatments (Table 5). Manganese leaves concentration was enhanced by compost addition, no matter the rate (Table 5).
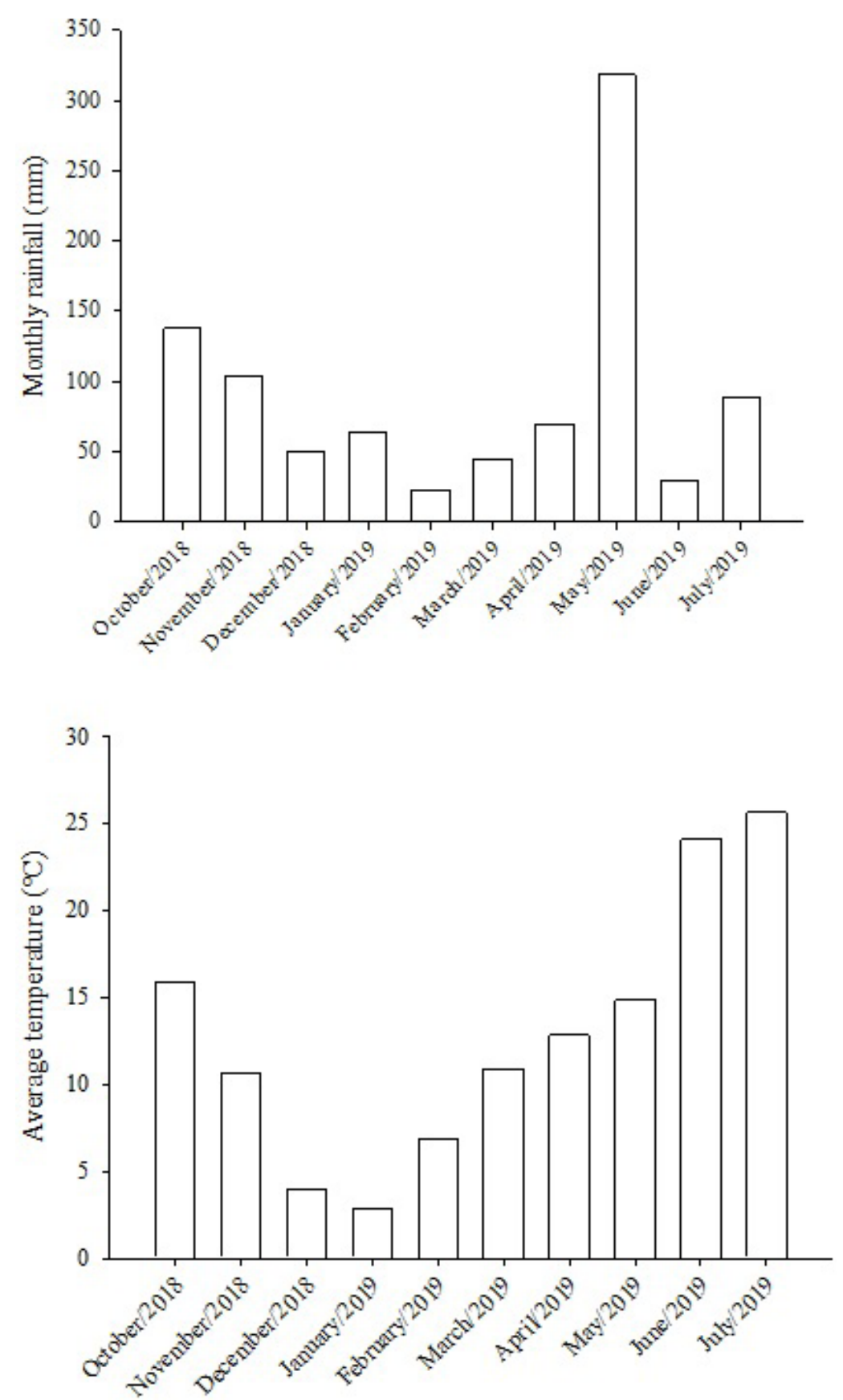

Figure 1. Monthly rainfall and average temperature during the experiment period in Forli-Cesena, Italy. 
Table 2. Effect of organic fertilization on nitrate-N concentration in soil of the cultivars Carene and Big Top.

\begin{tabular}{|c|c|c|c|c|c|c|c|}
\hline Compost $\left(\mathrm{t} \mathrm{ha}^{-1}\right)$ & January & February & March & April & May & June & July \\
\hline & \multicolumn{7}{|c|}{ Cv. Carene (mg NO $\left.{ }_{3}^{-}-\mathrm{N} \mathrm{kg}^{-1} \mathrm{dw}\right)$} \\
\hline 0 & $13.5 \mathrm{~b}$ & $7.52 \mathrm{~b}$ & $5.55 \mathrm{~b}$ & $21.7 \mathrm{~b}$ & $15.9 \mathrm{~b}$ & $16.0 \mathrm{a}$ & $5.88 \mathrm{~b}$ \\
\hline 20 & $45.1 \mathrm{a}$ & $25.2 \mathrm{a}$ & $21.2 \mathrm{a}$ & $42.7 \mathrm{a}$ & $21.8 \mathrm{a}$ & $8.16 \mathrm{~b}$ & $6.81 \mathrm{ab}$ \\
\hline 40 & $48.7 \mathrm{a}$ & $52.8 \mathrm{a}$ & $24.0 \mathrm{a}$ & $48.3 \mathrm{a}$ & $24.2 \mathrm{a}$ & $9.96 \mathrm{~b}$ & $9.06 \mathrm{a}$ \\
\hline \multirow[t]{2}{*}{ significance } & * & ** & * & * & $*$ & * & * \\
\hline & \multicolumn{7}{|c|}{ Cv. Big Top (mg NO$\left.{ }_{3}^{-}-\mathrm{N} \mathrm{kg}^{-1} \mathrm{dw}\right)$} \\
\hline 0 & $7.15 \mathrm{~b}$ & $5.77 \mathrm{~b}$ & $6.21 \mathrm{~b}$ & $17.3 \mathrm{~b}$ & $6.04 \mathrm{~b}$ & 5.96 & 11.6 \\
\hline 20 & $33.5 \mathrm{ab}$ & $10.8 \mathrm{~b}$ & $13.1 \mathrm{~b}$ & $24.6 \mathrm{~b}$ & $11.5 \mathrm{~b}$ & 7.39 & 25.4 \\
\hline 40 & $61.0 \mathrm{a}$ & $38.8 \mathrm{a}$ & $35.2 \mathrm{a}$ & $49.2 \mathrm{a}$ & $20.0 \mathrm{a}$ & 7.58 & 17.6 \\
\hline significance & ** & ** & ** & ** & ** & ns & ns \\
\hline
\end{tabular}

Averages followed by distinct lower case letters in the column differ from each other by the Tukey test at $5 \%$ probability of error. ns (not significant), * significant at $\mathrm{P} \leq 0.05$ and $* * \mathrm{P} \leq 0.01$.

Table 3. Effect of organic fertilization on ammonium concentration in soil of the cultivars Carene and Big Top

\begin{tabular}{lccccccc}
\hline Compost $\left(\mathrm{t} \mathrm{ha}^{-1}\right)$ & January & February & March & April & May & June & July \\
\hline 0 & \multicolumn{7}{c}{ Cv. Carene $\left(\mathrm{NH}_{4}^{+}-\mathrm{N} \mathrm{kg}^{-1} \mathrm{dw}\right)$} \\
20 & $2.66 \mathrm{~b}$ & 2.13 & 4.69 & 1.55 & 2.02 & 2.42 & 1.85 \\
40 & $2.61 \mathrm{~b}$ & 2.33 & 2.11 & 1.77 & 2.17 & 4.67 & 1.85 \\
significance & $3.80 \mathrm{a}$ & 3.56 & 4.18 & 1.88 & 2.02 & 2.29 & 1.99 \\
\hline
\end{tabular}

\begin{tabular}{lcccccccc}
\hline \multicolumn{7}{c}{ Cv. Big Top $\left(\mathrm{NH}_{4}^{+}-\mathrm{N} \mathrm{kg}^{-1} \mathrm{dw}\right)$} \\
\cline { 1 - 4 } & 3.04 & 2.17 & 2.00 & 1.62 & 2.47 & 2.17 & 1.77 \\
20 & 4.36 & 2.31 & 2.00 & 1.72 & 2.55 & 1.65 & 2.07 \\
40 & 3.15 & 2.11 & 2.13 & 1.81 & 2.47 & 3.89 & 1.97 \\
significance & $n s$ & $n s$ & $n s$ & $n s$ & $n s$ & $n s$ & $n s$ \\
\hline
\end{tabular}

Averages followed by distinct lowercase letters in the column differ from each other by the Tukey test at $5 \%$ probability of error. ns (not significant), * significant at $\mathrm{P} \leq 0.05$. 
Table 4. Effect of organic fertilization and crop load on leaves macronutrient and micronutrient concentrations in the cultivar Carene

\begin{tabular}{lcccccc}
\hline & $\mathbf{N}$ & $\mathbf{P}$ & $\mathbf{K}$ & $\mathbf{C a}$ & Mg & S \\
\hline Compost $\left(\mathrm{t} \mathrm{ha}^{-1}\right)$ & \multicolumn{7}{c}{ \% dw } \\
\hline 0 & 2.74 & 0.193 & 2.32 & 2.57 & 0.385 & 0.136 \\
20 & 2.63 & 0.197 & 2.29 & 2.71 & 0.398 & 0.135 \\
40 & 2.78 & 0.197 & 2.23 & 2.58 & 0.391 & 0.138 \\
significance & $n s$ & $n s$ & $n s$ & $n s$ & $n s$ & $n s$ \\
\hline
\end{tabular}

\section{Fruit load}

\begin{tabular}{lllllll}
\hline High & 2.66 & 0.200 & 2.30 & 2.73 & 0.398 & 0.136 \\
\cline { 1 - 5 } Low & 2.77 & 0.197 & 2.28 & 2.51 & 0.385 & 0.136
\end{tabular}

significance

ns

\begin{tabular}{|c|c|c|c|c|c|}
\hline & $\mathrm{Cu}$ & $\mathbf{F e}$ & Mn & Zn & B \\
\hline $\operatorname{Compost}\left(\mathrm{t} \mathrm{ha}^{-1}\right)$ & & & $n g \mathrm{~kg}^{-1} \mathrm{~d}$ & & \\
\hline 0 & 11.470 & $73.002 \mathrm{~b}$ & 20.252 & 23.387 & 31.982 \\
\hline 20 & 10.886 & $78.403 \mathrm{a}$ & 19.331 & 23.016 & 31.982 \\
\hline 40 & 10.432 & $78.430 \mathrm{a}$ & 19.250 & 23.723 & 29.290 \\
\hline significance & $n s$ & * & $n s$ & $n s$ & $n s$ \\
\hline
\end{tabular}

\section{Fruit load}

\begin{tabular}{llllll}
\hline High & 11.308 & 76.439 & 18.836 & 23.316 & 31.172 \\
Low & 10.550 & 76.785 & 20.385 & 23.435 & 30.381
\end{tabular}

significance

ns

ns $n s$

Averages followed by distinct lowercase letters in the column differ from each other by the Tukey test at $5 \%$ probability of error. ns
and *: not significant, or significant at $5 \%$ probability of error, respectively.

Application of $40 \mathrm{t} \mathrm{ha}^{-1}$ may have increased humic and fulvic fractions that form stable and soluble complexes with Fe (SORRENTI et al., 2011; SORRENTI et al., 2012). In addition, organic fertilization stimulates root and microorganism activities, increases Fe availability in rhizosphere, keeping the nutrient available for plants (SORRENTI et al., 2011).

The supply of compost did not induce any increase of fruit diameter during the season neither in Carene nor in Big Top (Figure 2). On the other hand, crop load induced a increase of fruit diameter in plants with low fruit load in compassion to that with high fruit load in both varieties (Figure 3).
According to Castro and Barbieri (2014), fruit growth comprises three phases. The first one begins with blooming and is characterized by cytochines (fast cell multiplication). In the second phase, growth is slow, while in the third one (cell enlargement), growth is fast and ends in fruit maturation. In this study showed that fruit diameter was not affected by fruit load per plant in the first 2 stages; while after pit hardening plants with low fruit load induced and increase of fruit diameter. In high crop load, C competition among fruits and between fruits and shoots, prevented fruit to reach a size optimal for the market $(>67 \mathrm{~mm})$ as also evidenced by the fruit weight measured at harvest (Table 6). 
Table 5. Effect of organic fertilization and crop load on leaves macronutrient and micronutrient concentrations in the cultivar Big Top.

\begin{tabular}{lcccccc}
\hline & N & P & K & Ca & Mg & S \\
\hline Compost $\left(\mathrm{t} \mathrm{ha}^{-1}\right)$ & \multicolumn{7}{c}{$\% \mathrm{dw}$} \\
\hline 0 & 2.70 & 0.178 & 2.00 & 3.15 & 0.411 & 0.141 \\
20 & 2.96 & 0.188 & 1.95 & 2.75 & 0.510 & 0.155 \\
40 & 2.93 & 0.177 & 1.87 & 2.91 & 0.415 & 0.152
\end{tabular}

significance

ns $\quad$ ns

$n s \quad n s$

$n s$

$n s$

\section{Fruit load}

\begin{tabular}{|c|c|c|c|c|c|}
\hline High & 2.87 & 0.181 & 3.07 & 0.420 & 0.147 \\
\hline Low & 2.87 & 0.181 & 2.81 & 0.423 & 0.151 \\
\hline \multirow[t]{2}{*}{ significance } & $n s$ & $n s$ & $n s$ & $n s$ & $n s$ \\
\hline & $\mathrm{Cu}$ & $\mathrm{Fe}$ & Mn & $\mathrm{Zn}$ & B \\
\hline Compost $\left(\mathrm{t} \mathrm{ha} \mathrm{C}^{-1}\right)$ & \multicolumn{5}{|c|}{$m g \mathrm{~kg}^{-1} \mathrm{dw}$} \\
\hline 0 & 13.3 & $70.5 \mathrm{~b}$ & $39.6 \mathrm{~b}$ & 27.8 & 38.4 \\
\hline 20 & 12.8 & $74.8 \mathrm{ab}$ & $48.6 \mathrm{a}$ & 29.1 & 36.7 \\
\hline 40 & 14.5 & $76.9 \mathrm{a}$ & $49.3 \mathrm{a}$ & 34.3 & 35.1 \\
\hline significance & $n s$ & $*$ & $* *$ & $n s$ & $n s$ \\
\hline \multicolumn{6}{|l|}{ Fruit load } \\
\hline High & 13.6 & 73.0 & 43.6 & 32.5 & 37.2 \\
\hline Low & 13.6 & 75.2 & 48.0 & 28.3 & 36.3 \\
\hline significance & $n s$ & $n s$ & $n s$ & $n s$ & $n s$ \\
\hline
\end{tabular}

Averages followed by distinct lowercase letters in the column differ from each other by the Tukey test at $5 \%$ probability of error. ns: not significant at $5 \%$ probability of error. * significant at $\mathrm{P} \leq 0.05$ and $* * \mathrm{P} \leq 0.01$. 


\section{Cv. Carene}

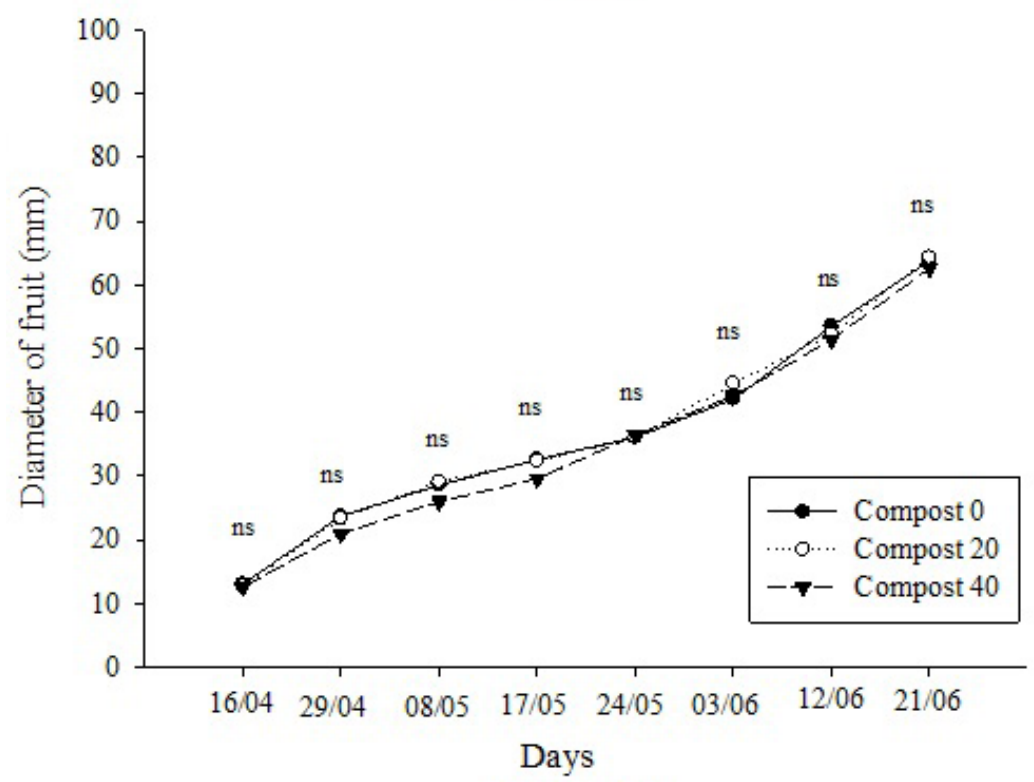

Cv. Big Top

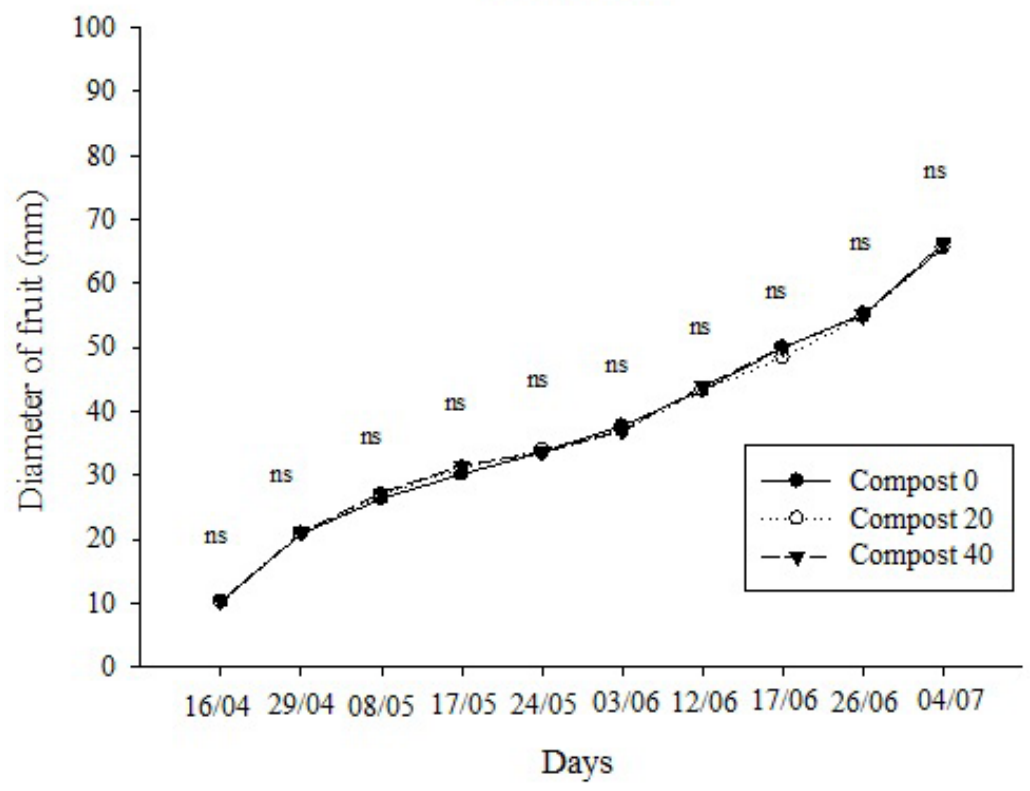

Figure 2. Effect of compost addition on fruit diameter during the vegetative season in Carene and Big Top. ns $=$ not significant. 

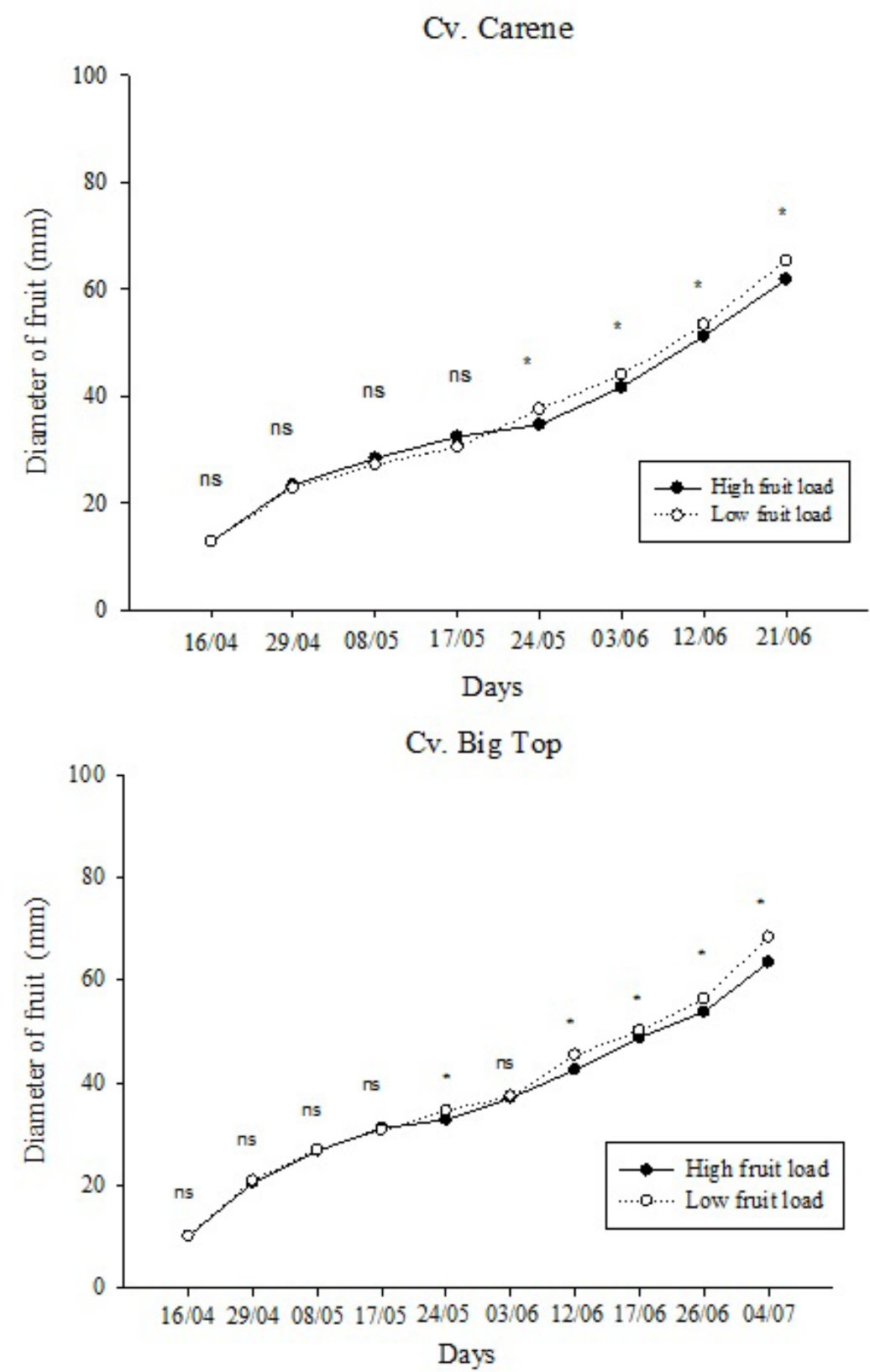

Figure 3. Effect of high and low fruit load in diameter during the vegetative season in Carene and Big Top. ns $=$ not significant. * significant at $5 \%(\mathrm{P} \leq 0.05)$ 
Table 6. Effect of organic fertilization and crop load on yield, number of fruits, fruit weight, pulp firmness and soluble solids concentration (SSC) of the cultivar Carene and Big Top

\begin{tabular}{|c|c|c|c|c|c|}
\hline $\begin{array}{c}\text { Compost } \\
(\mathrm{t} \mathrm{ha-1)})\end{array}$ & $\begin{array}{c}\text { Yield } \\
\left(\mathrm{kg}^{\text {tree }}{ }^{-1}\right)\end{array}$ & $\begin{array}{c}\text { Fruit } \\
\left.\text { (n. tree }{ }^{-1}\right)\end{array}$ & $\begin{array}{l}\text { Fruit weight } \\
\quad\left(\mathrm{g} \text { fruit }^{-1}\right)\end{array}$ & $\begin{array}{c}\text { Firmness } \\
(\mathrm{kg})\end{array}$ & $\begin{array}{c}\text { SSC } \\
\left({ }^{\circ} \text { Brix }\right)\end{array}$ \\
\hline \multicolumn{6}{|c|}{ Cv. Carene } \\
\hline 0 & 15.3 & 124 & 126 & 6.54 & 12.08 \\
\hline 20 & 16.1 & 133 & 121 & 6.57 & 13.7 \\
\hline 40 & 16.8 & 145 & 114 & 6.29 & 12.3 \\
\hline significance & $n s$ & $n s$ & $n s$ & $n s$ & $n s$ \\
\hline \multicolumn{6}{|l|}{ Fruit load } \\
\hline High & 15.8 & 140 & 112 & 6.51 & 12.4 \\
\hline Low & 16.3 & 127 & 130 & 6.43 & 13.0 \\
\hline significance & $n s$ & $*$ & * & $n s$ & $n s$ \\
\hline compost $x$ fruit load & $n s$ & $n s$ & $n s$ & $n s$ & $n s$ \\
\hline \multicolumn{6}{|c|}{ Cv. Big Top } \\
\hline 0 & 19.1 & 108 & 135 & $5.42 \mathrm{~b}$ & 12.0 \\
\hline 20 & 19.3 & 100 & 157 & $5.54 \mathrm{~b}$ & 12.1 \\
\hline 40 & 17.2 & 108 & 121 & $5.86 \mathrm{a}$ & 11.9 \\
\hline significance & $n s$ & $n s$ & $n s$ & $n s$ & $n s$ \\
\hline \multicolumn{6}{|l|}{ Fruit load } \\
\hline High & 20.0 & 105 & 115 & 5.60 & 12. 1 \\
\hline Low & 17.1 & 90 & 146 & 5.61 & 12.0 \\
\hline significance & $n s$ & $*$ & ${ }^{*}$ & $n s$ & $n s$ \\
\hline compost $x$ fruit load & $n s$ & $n s$ & $n s$ & $n s$ & $n s$ \\
\hline
\end{tabular}

Averages followed by distinct lowercase letters in the column differ from each other by the Tukey test at $5 \%$ probability of error. ns and *: not significant, or significant at $5 \%$ probability of error, respectively. $*$ significant at $\mathrm{P} \leq 0.05$.

Fertilization and fruit load did not interact for yield and quality fruit parameters. Organic fertilization did not influence yield, number of fruits per plant, fruit weight and soluble solids in both cultivars (Table 6). Even the application of a high rate of compost and the consequent excess of nitrate-N availability in soil did not show any effect in plant production and fruit size, showing that soil fertility was not able to increase fruit size in the trees with high crop load. Consequently, it is not worth using high compost rates to trigger increase in production, above the optimal level of soil fertility. It should also be highlighted that the orchard is conducted according to organic management techniques (in transition to biodynamic agriculture); consequently, it is characterized by good concentration of organic matter (around 2\%) and soil fertility (Table 1). Thus, this fact could be associated with the lack of response given by organic fertilization in this study. In addition, the present data only refer to one year period, that, for fruit trees is quite short to get significant results as also previously observed in other experiment on peach (TOSELLI et al., 2019a).
Only in the variety Big Top, plants fertilized with the compost at $40 \mathrm{t} \mathrm{ha}^{-1}$ produced fruits with high pulp firmness (Table 6), which was probably related to a delay in fruit maturation that is due to high $\mathrm{N}$ availability. In addition, it was observed that a greater fruit load leads to a smaller fruit caliber, and fruits with smaller caliber show greater firmness. In both cultivars, although fruit number was higher in non-manually thinned plots (high fruit load) compared to thinned trees (low fruit load), yield was not affected by crop loads mainly because fruit weight (Table 6) and diameter (Figure 3) were similar among treatments. Plants with high load exhibited the larger number of fruits per plant; however, they resulted in a reduction of size of $21.2 \%$ and $13.9 \%$, for Big Top and Carene, respectively, compared to the low crop load. Therefore, excess of fruit in plants increases carbohydrate competition and affects distribution of photo assimilates among fruit negatively (TUSTIN et al. 2012; MEITEI et al., 2013). In a previous experiment using compost at the same rate, it was evidenced that the application of compost delayed fruit ripening (BALDI et al., 2012) while the quality of fruits during cold storage and shelf life was not influenced by the fertilization treatments. 


\section{Conclusion}

The main issue of compost supply is having excess of nitrate available in period when plants not need them, with a consequent ground water contamination. In the present experiment, the use of high rate of organic fertilizer lead to excess nitrate release in soil in the first part of the season, when plants are still in vegetative rest. The solution to overcome this problem could be to split compost supply in spring, so that it gives nutrient to plants during the vegetative season, and, with lower rate, in autumn to replenish plant reserves. Iron in the leaves increased as a consequence of organic fertilizer. The size of the fruit had no influence on the number of fruits and was lower in high compared to low harvest load.

\section{Acknowledgment}

The University of Bologna (Italy) and the National Council for Scientific and Technological Development (CNPq, Brazil) for granting the scholarship.

Regione Emilia Romagna (PSR 2014-2020 16.1.01 Biodinamicanova) and Farm Valerio Balzani, via Molino Selbagnone, Bertinoro (FC) for hosting the trial.

\section{References}

AMARANTE, C.V.T.D.; STEFFENS, C.A.; MAFRA, Á.L.; ALBUQUERQUE, J.A. Yield and fruit quality of apple from conventional and organic production systems. Pesquisa Agropecuária Brasileira, Brasília, DF, v.43, n. 3, p.333-340, 2008.

AMIRI, M.E.; FALLAHI, E. Impact of animal manure on soil chemistry, mineral nutrients, yield, and fruit quality in 'Golden Delicious' apple. Journal of Plant Nutrition, Philadelphia, v.32, n.4, p.610-617, 2009.

AMODIO, M.L.; COLELLI, G.; HASEY, J.K.; KADER, A.A. A comparative study of composition and postharvest performance of organically and conventionally grown kiwifruits. Journal of the Science of Food and Agriculture, New York, v.87, n.7, p.1228-1236, 2007.

ASLANTAS, R.; ANGIN, I.; KOBAZA, A.O. Longterm effects of sewage sludge application on sour cherry (Prunus cerasus L.). Israel Journal of Plant Sciences, Jerusalem, v.61, p.51-56 2013.
BALDI，E.; TOSELLI，M.; MARCOLINI，G.; QUARTIERI, M.; INNOCENTI, A.; MARANGONI, B. Effect of organic fertilization, ripening stage and storage on quality of fruits of 'Stark Redgold' nectarine. Acta Horticulturae, The Hague, v.933, p.593-600, 2012.

BALDI, E.; MARCOLINI, G.; QUARTIERI, M.; SORRENTI, G.; MUZZI, E.; TOSELLI, M. Organic fertilization in nectarine (Prunus persica var. nucipersica) orchard combines nutrient management and pollution impact. Nutrient Cycling in Agroecosystems, Dordrecht, v.105, p.39-50, 2016.

BALDI, E.; TOSELLI, M. Mineralization dynamics of different commercial organic fertilizers from agro-industry organic waste recycling: an incubation experiment. Plant, Soil and Environment, Prague, v.60, n.3, p.93-99, 2014.

BOZKURT, M.A.; YARILGAÇ, T.; YAZICI, A. The use of sewage sludge as an organic matter source in apple trees. Polish Journal of Environmental Studies, Olsztyn, v.19, n.2, p.267-274, 2010.

BUSSI, C.; LESCOURRET, F.; GENARD, M. Effects of thinning and pruning on shoot and fruit growths of girdled fruit-bearing shoots in two peach tree cultivars (Big Top and Alexandra). European Journal of Horticultural Science, Stuttgart, v.74, n.3, p.97-102, 2009.

CABAllero, R.; PAJUElo, P.; ORdOVÁS, J.; CARMONA, E.; DELGADO, A. Evaluation and correction of nutrient availability to Gerbera jamesonii $\mathrm{H}$. Bolus in various compost-based growing media. Scientia Horticulturae, New York, v.122, n.2, p.244-250, 2009.

CASTRO, L.A.S.; BARBIERI, R.L. Botânica e morfologia do pessegueiro. In: RASEIRA, M.C.B.; PEREIRA, J.F.M.; CARVALHO, F.L.C. (ed.). Pessegueiro. Brasília (DF): Embrapa, 2014. p.25-43.

DIACONO, M.; MONTEMURRO, F. Long-term effects of organic amendments on soil fertility. A review. Agronomy for Sustainable Development, Amsterdam, v.30, p.401-422, 2010.

ERNANI, P.R. Química do solo e disponibilidade de nutrientes. 2.ed. Lages: Paulo Ernani, 2016. 256 p. 
FARIAS, R. DE M.; BARRETO, C.F.; ZANDONÁ, R.R.; MARTINS, C.R.; MELLO-FARIAS, P.; MARODIN, G.A.B. Chemical thinning of 'BRS Kampai' peach trees. Pesquisa Agropecuária Brasileira, Brasília, DF, v.54, e01353, 2019.

FERREIRA, D.F. Sisvar: a guide for its bootstrap procedures in multiple comparisons. Ciência e Agrotecnologia, Lavras, v.38, p.109-112, 2014.

GOSS, M.J.; TUBEILEH, A.; GOORAHO, D. A review of the use of organic ammendaments and risk to human health. Advances in Agronomy, San Diego, v.120, p.275379, 2013.

JADOSKI, S.O.; SAITO, L.R.; PRADO, C.; LOPES, E.C.; SALES, L.L.S.R. Características da lixiviação de nitrato em áreas de agricultura intensiva. Pesquisa Aplicada \& Agrotecnologia, Guarapuava, v.3, n.1, p.193-200, 2010.

LORENZINI, F.; CERETTA, C. A.; GIROTTO, E.; CERINI, J. B.; LOURENZI, C. R.; CONTI, L. TRINDADE, M. M.; MELO, G. W.; BRUNETTO, G. Lixiviação e volatilização de nitrogênio em um Argissolo cultivado com videira submetida à adubação nitrogenada. Ciência Rural, Santa Maria, v.42, p.1173- 1179, 2012.

MAHADEEN, A.Y. Influence of organic and chemical fertilization on fruit yield and quality of plastic house grown strawberry. Jordan Journal of Agricultural Sciences, Amman, v.5, n.2, p.167-177, 2009.

MARZOUK, H.A.; KASSEM, H.A. Improving fruit quality, nutritional value and yield of Zaghloul dates by the application of organic and/or mineral fertilizers. Scientia Horticulturae, Wageningen, v.127, n.3, p.249254, 2011.

MEITEI S.B.; PATEL, R.K.; DEKA, B.C.; DESHMUKH, N.A.; SINGH, A. Effect of chemical thinning on yield and quality of peach cv. Flordasun. African Journal of Agricultural Research, Nairobi, v.8, p.3358-3565, 2013.
OLIVEIRA, P.D. de; MARODIN, G.A.B.; ALMEIDA, G.K. de; GONZATTO, M.P.; DARDE, D.C. Heading of shoots and hand thinning of flowers and fruits on 'BRS Kampai' peach trees. Pesquisa Agropecuária Brasileira, Brasília, DF, v.52, p.1006-1016, 2017.

POWLSON, D.S.; GREGORY, P.J.; WHALLEY, W.R.; QUINTON, J.N.; HOPKINS, D.W.; WHITMORE, A.P.; HIRSCH, P.R.; GOULDING, K.W.T. Soil management in relation to sustainable agriculture and ecosystem services. Food Policy, Oxford, v.36, p.72-87, 2011.

PRANGE, R.K, Fruit and vegetable quality as affected by the use of compost and other organic amendments. Acta Horticulturae, The Hague, v.1076, p.127-136, 2015.

ROUSSOS, p.A.; GASPARATOS, D.; KECHROLOGOU, K.; KATSENOS, P.; BOUCHAGIER, P.; Impact of organic fertilization on soil properties, plant physiology andyield in two newly planted olive (Olea europaea L.) cultivars under Mediterranean conditions. Scientia Horticulturae, New York, v.220, p.11-19, 2017.

SCIUBBA, L.; CAVANI, L.; GRIGATTI, M.; CIAVATTA, C.; MARZADORI, C. Relationships between stability, maturity, water-extractable organic matter of municipal sewage sludge composts and soil functionality. Environmental Science and Pollution Research, Landsberg, v.22, n.17, p.13393-13403, 2015.

SMITH, J.L.; COLLINS, H.P. Composting. In: PAUL, E.A. (ed.). Soil microbiology, ecology, and biochemistry. 3.ed. Burlington: Academic Press, 2007. p.483-486.

SORRENTI, G.; TOSELLI, M. Soil leaching as affected by the amendment with biochar and compost. Agriculture, Ecosystems and Environment, Amsterdam, v.226, p.56-64, 2016.

SORRENTI, G.; TOSELLI, M.; BALDI, E; QUARTIERI, M.; MARCOLINI, G.; BRAVO, K.; MARANGONI, B. L'importanza della sostanza organica nella gestione sostenibile del suolo per una frutticoltura efficiente. Rivista di Frutticoltura e Ortofloricoltura, Bologna, v.3, p.12-16, 2011. 
SORRENTI, G.; TOSELLI, M.; MARANGONI, B. Use of compost to manage Fe nutrition of pear trees grown in calcareoussoil. Scientia Horticulturae, New York, v.136, p.87-94, 2012.

TAGLIAVINI, M.; SCUDELLARI, D.; MARANGONI, B.; TOSELLI, M. Nitrogen fertilization management in orchards to reconcile productivity and environmental aspects, Fertilizer Research, Dordrecht, v.43, p.93-102, 1996.

TAN, B.Z.; BOUND, S.A.; EYLES, A. Impact of management regimes on fruit quality of sweet cherry (Prunus avium L.). Agroecology and Sustainable Food Systems, Philadelphia, v.42, n.5, p.493-503, 2018.

TOSELLI, M.; BALDI, E.; CAVANI, L.; MAZZON, M.; QUARTIERI, M.; SORRENTI, G.; MARZADORI, C. Soil-plant nitrogen pools in nectarine orchard in response to long-term compost application. Science of the Total Environment, New York, v.671, p.10-18, 2019a.
TOSELLI, M.; BALDI, E.; CAVANI, L.; SORRENTI, G. Nutrient management in fruit crops: an organic way. In: SRIVASTAVA, A.K.; CHENGXIAO, H. (ed.). Fruit crops: diagnosis and management of nutrients constraints. Amsterdam: Elsevier, 2019b. p.379-390.

TUSTIN, D.S.; DAYATILAKE, G.A. BREEN, K.C. OLIVER, M.J. Fruit set responses to changes in flo-ral bud load - a new concept for crop load regulation. Acta Horticulturae, New York, v.932, p.195-202, 2012.

WOOLF, D.; AMONETTE, J.E.; STREET-PERROTT, F.A.; LEHMANN, J.; JOSEPH, S. Sustainable biochar to mitigate global climate change. Nature Communications, London, v.1, n.5, p.56, 2010.

ZOPPAS, F.M.; BERNARDES, A.M.; MENEGUZZI, A. Parâmetros operacionais na remoção biológica de nitrogênio de águas por nitrificação e desnitrificação simultânea. Sanitary Engineering Journal, Rio de Janeiro, v.21, n.1, p.29-42, 2016. 